\title{
A year in review: basic science
}

Lucy R Wedderburn

From 21st European Pediatric Rheumatology (PReS) Congress

Belgrade, Serbia. 17-21 September 2014

The year of September 2013 - 2014 has seen some seminal discoveries in the field of human autoimmunity and immunology : work in Paediatric Rheumatology has led the way in several of these. In this session we will review together some of the exciting and important new developments in basic understanding of disease pathogenesis. We will also hear of the application of high throughput techniques and large datasets to our understandings of mechanism and to our translational goals towards improving lives of our patients.

However one small note of caution - it is never possible to review everything of high importance and relevance, so apologies in advance if some studies cannot be squeezed in.

\section{Disclosure of interest}

None declared.

Published: 17 September 2014

doi:10.1186/1546-0096-12-S1-I1

Cite this article as: Wedderburn: A year in review: basic science. Pediatric Rheumatology 2014 12(Suppl 1):11.

Submit your next manuscript to BioMed Central and take full advantage of:

- Convenient online submission

- Thorough peer review

- No space constraints or color figure charges

- Immediate publication on acceptance

- Inclusion in PubMed, CAS, Scopus and Google Scholar

- Research which is freely available for redistribution
() Biomed Central

(c) 2014 Wedderburn; licensee BioMed Central Ltd. This is an Open Access article distributed under the terms of the Creative Commons Attribution License (http://creativecommons.org/licenses/by/4.0), which permits unrestricted use, distribution, and reproduction in any medium, provided the original work is properly cited. The Creative Commons Public Domain Dedication waiver (http://creativecommons.org/publicdomain/zero/1.0/) applies to the data made available in this article, unless otherwise stated. 